\title{
Influence of Hagia Sophia on the Construction of Dome in Mosque Architecture
}

\author{
Dr. Saqer Sqour ${ }^{1}$
}

\begin{abstract}
This paper discusses the influence of the revolutionary pendentive dome of the 6th century church Hagia Sophia on building domes. The paper aims to track the impact of the structure of the dome of Hagia Sophia on Muslim mosques. It, also aimed to compare the Hagia Sophia building with selected Ottoman mosques. The study has begun analyzing the construction of the dome of Hagia Sophia. Its structure comes due the transition from erecting half spherical dome on circular plan to be above a square plan. Further, a creative architectural component in the history of domes helped to achieve such transition that is the pendentive arches. These arches formed a challenge for several architects and engineers to compete with this design, including the well-known architect Sinan Agha.

This study presents different cases of buildings with domes influenced by Hagia Sophia, some of them belonging to Ottoman Period, while others are of those built later. It shows the dome of Hagia Sophia influenced majority of Ottoman mosques. Example: Sultan Ahmed or the Blue Mosque, Suleymaniye Mosque and Shahzadah Mosque in Istanbul, and Muhammad Ali mosque in Egypt. However, necessary pictures, diagrams and sketches helped to conduct this study.
\end{abstract}

Keywords - Domes, Hagia Sophia, mosque domes, Ottoman mosques.

\section{INTRODUCTION}

\section{TMPORTANCE of the study:}

Importance comes from the need of elaborating influence of the dome of Hagia Sophia on Muslim mosques, and describing how to build domes over square plans.

\section{Background:}

Dome is a projected circular architectural element used to cover buildings, began in Mesopotamia in the fourth millennium BC, and developed by the Romans and Byzantines. There are various forms of domes such as onion shape, a half circle and ellipse. The dome has a complete ability to withstand pressure loads of construction.

In the Mesopotamian Royal Cemetery of the city of Ur, there was a true dome with pendentives rounding off the angles of the square chamber. That was a rubble dome found among the chambers of the tombs, dating to 2500 B.C. Such dome was made from mud mortar. Besides, there were other small domes, in the courtyard of Ur ziggurat, and in later

\footnotetext{
${ }^{1}$ Saqer Sqour, Associate Professor, Architecture Department, Al al-Bayt University, Jordan. Director of Architecture and Interior Architecture, Al Yamamah University, Riyadh, KSA.
}

shrines and temples of the 14th century B.C [1].

During the Romans, domes had a noticeable development. They added new materials for construction to stand as long as possible against erosion and environment. Among the utmost famous domes was the dome of the Pantheon in Rome; one of the largest domes ever erected. Its height, as well as diameter, is 43.3 meters. The Pantheon remains the distinguished building that has survived in excellent condition till today. It bears the architect's name on its facade. Further, the only light entering the building is through the upper opening of the dome and its doorway.

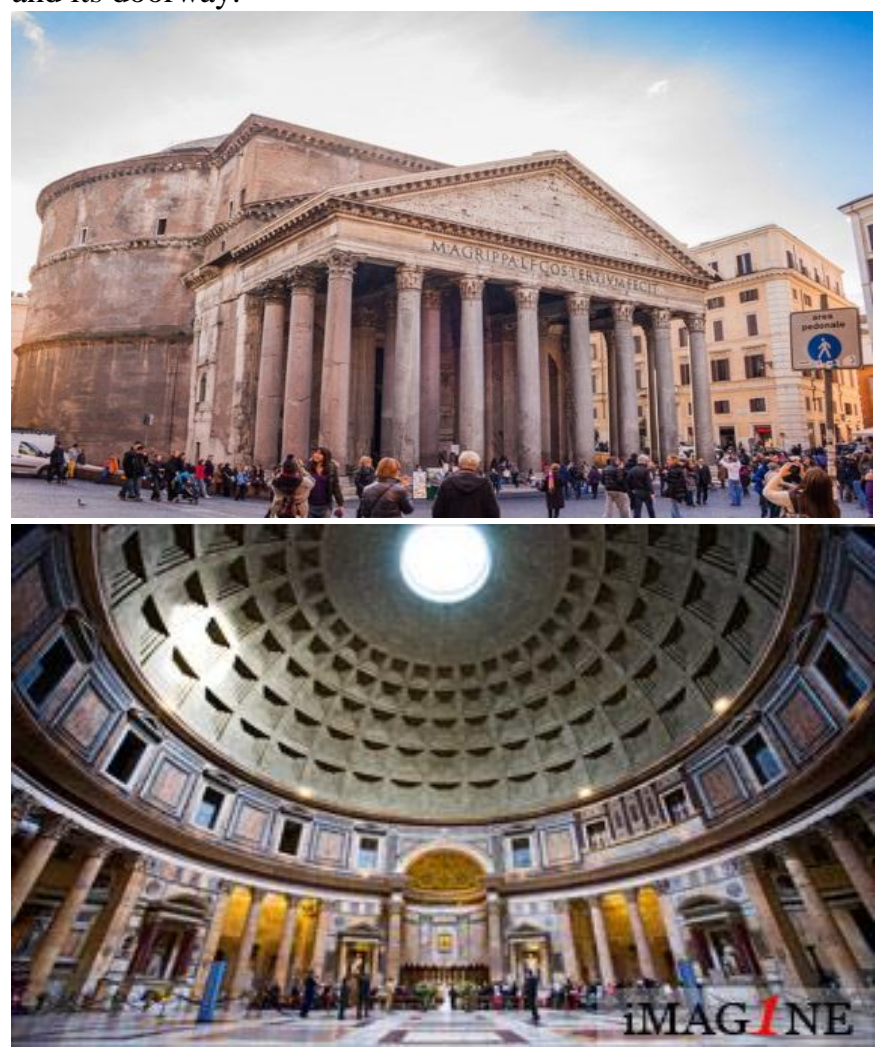

Fig. 1 represents Pantheon in Rome, Italy, (Exterior) and (Interior)

\section{Previous Studies:}

There are various studies conducted on the design and structure of Hagia Sophia In literature. Further, there are several studies concerning the influence of Byzantine on the architecture of mosques. Besides, fewer are on the impact of pendentives of Hagia Sophia on Mosque Architecture. Although, several of them can assist this study:

1. Virtual Hagia Sophia: Restitution, Visualization and Virtual Life Simulation by Alessandro E. F. and George 
Papagiannakis Nadia, Magnenat-Thalmann Miralab cui, University of Geneva, Geneva, Switzerland

This study focused on virtual response simulation virtual life of the complex of Hagia Sophia in Istanbul, Turkey. Hagia Sophia was added in 1996 in the annual list of monuments endangered. The aim of this article is to describe techniques used to achieve a realistic simulation of specific area and its characters, as well to point out the challenges and solutions involved in such work.

2. The Hagia Sophia \& the Influence of the Byzantine Culture on Religious Buildings by Leah Regan. This research aims to study the history of Byzantine architecture by studying Hagia Sophia. It discusses the impact of this building on religious buildings created later. Thus, it tackles the same issue of this paper, but this paper discusses only the Muslim religious buildings, focusing on the impact on both ancient and modern mosques from different countries.

3. Daylighting Analysis of Pendentive Dome's Mosque Design during Summer Solstice with Case Studies in Istanbul, Turkey.

This study aims to analysis and measure the lighting performance of one pendentive dome in the design of the mosques. The case studies are Firuzaga and Orhan Gazi Mosque in Istanbul. This study examines whether the pendentive dome provides an effective internal day light. It applies simulation analysis. Finally, it assumes the pendentive dome gave out an excellent illuminance at all locations. Therefore, Muslim architects built majority of mosques with a pendentive dome roof.

\section{THE HAGIA SOPHIA}

Hagia Sophia means "holy wisdom," a domed monument built as a cathedral in Constantinople in the sixth century A.D. It consists of two floors with a large dome. In plan it is around 82 meters long and 73 meters wide. The dome is 33 meters in diameter, with a height of 55 meters above the ground level. During its 1,400 year life-span it was a cathedral, mosque and a museum [2].

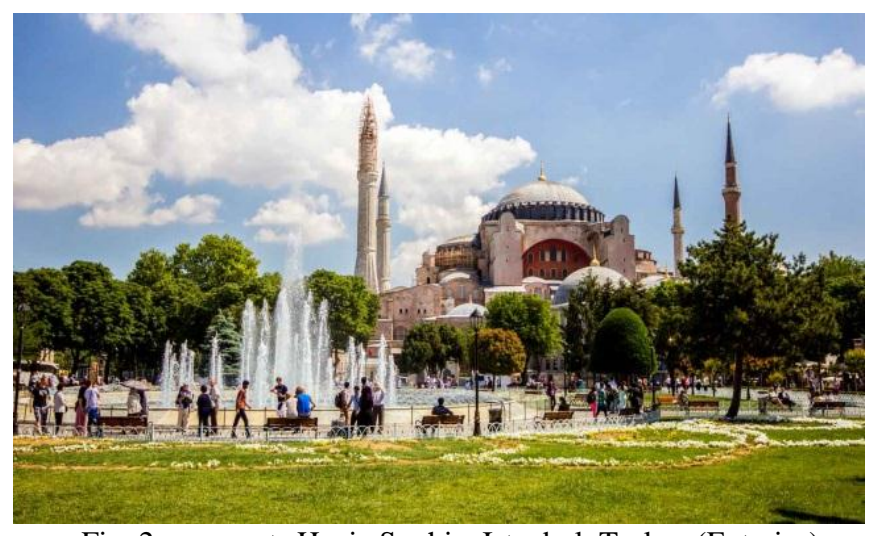

Fig. 2 represents Hagia Sophia. Istanbul, Turkey (Exterior)

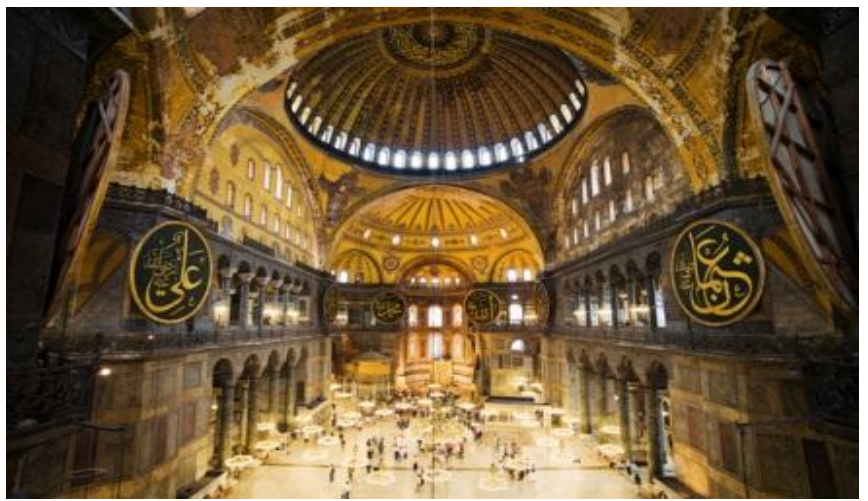

Fig. 3 represents Hagia Sophia. Istanbul, Turkey (Interior). The crown of the dome rises 55 meters above the floor.

To build Hagia Sophia, Justinian chose two men named Anthemius and Isidore the Elder, who were not considered as architects, but mechanopoioi [3].

They built the Hagia Sophia in six years. Although, they had problems with the dome roof; therefore, the dome collapsed first during construction, after that two decades later. Thus, Isidore the Younger was nominated to build a new roof, which lasted to the present-day. Hagia Sophia was so distinguished that Durant wrote "It was never on earth since Adam, and it is not possible to construct again" [4]. Also, Hagia Sophia forms a combination of both the domed hall and the projected vaulted rectangular hall [5]

"The dome rests not on a drum rather on pendentives: a spherical triangles that arise from four massive piers that carry the weight of the cupola. The pendentives made it possible to place the dome over a square compartment" [6].

The dome of Hagia Sophia was a significant turn in the history of building construction. This importance comes from being a transformation from circular to square plan [7]. Although, this particular design, circular dome over square base, is rooted in Persian mausoleums and fire temples [8].
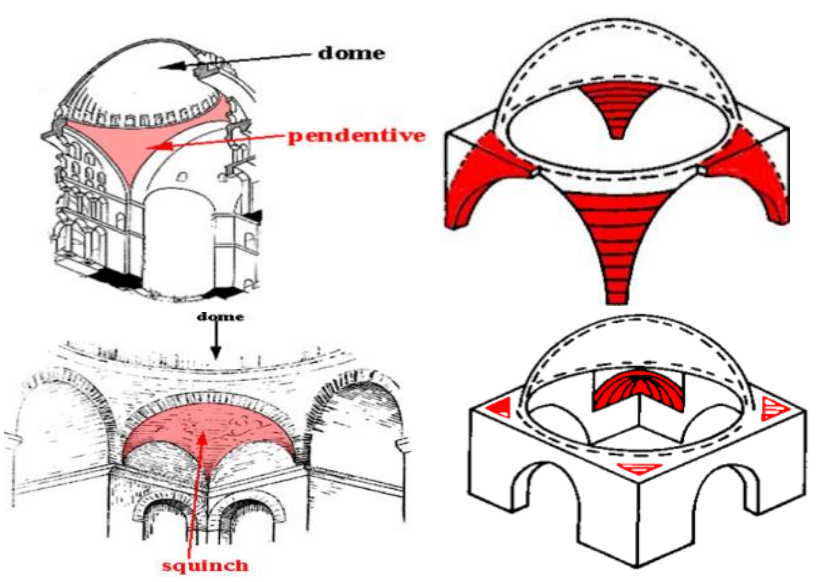

Fig. 4 shows transferring dome to a square plan by pendentives.

\section{Conversion to mosque}

Another period in Hagia Sophia's life started in 1453. It was the year when the Byzantine Empire ended, and when the Ottoman decided to convert Hagia Sophia into a masjid [9].

Outside the building, four minarets were added [10], these 
"four slender pencil-shaped minarets" are above 60 meters high and are "among the tallest ever constructed." Finally, In 1934, the government of Turkey secularized the Hagia Sophia and turned it into a museum [11].

\section{DOMES IN MUSLIM ARCHITECTURE}

Although, dome stands the greatest architectural innovation, and its evolution was before Islam, but Muslim architects developed or introduced numerous domes. In the Islamic era Muslim architects developed have enormous and varied types of domes like: smooth, ribbed and conical with neck [12].

The first dome known in Islam is the Dome of the Rock; it was built by Abdul Malik bin Marwan, followed by the Dome of Eagle in the Umayyad Mosque built by Walid bin Abdul Malik. Later, Muslims increased using domes to have a dome for every mosque. Also, they used them above the shrines and palaces [13].

The following are some of Muslim masterpieces throughout history of Islam. These buildings were influenced mainly by the Byzantine Hagia Sophia:

\section{Dome of the Rock Mosque}

\section{Jerusalem, Palestine:}

The first Muslim masterpiece; it was built in 687 A.C. by Caliph Abd al-Malik, half a century after the death of the Prophet Muhammad [14].

The diameter of the outer dome is 21 meters, the inner dome 20 meters. The original 1 st century outer dome was copper. Hence, it was converted to lead in the 9th century [15].

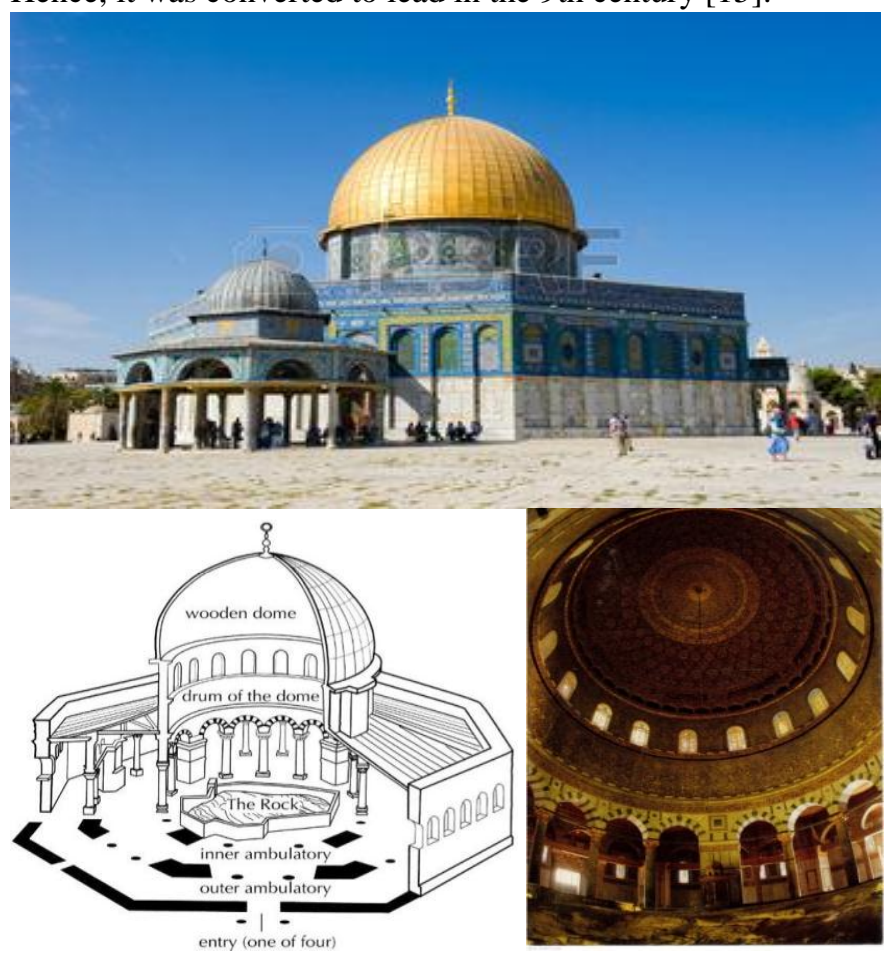

Fig. 5 represents Dome of the Rock, Jerusalem, Palestine, (exterior) (Section) and (Interior) [16]

The dome of this mosque has same measurements for both diameter and height; it resists more than that of Byzantine churches, for, being made of wood. Its weight does not compel, as in vaults made of stone, those buttresses or side cupolas that weight down the external outline of Hagia Sophia and the monuments inspired by it [17]

\section{Umayyad Masjid, Eagle Dome:}

\section{Damascus, Syria:}

The Dome of the Eagle (Qubbat Al-Nisr) is considered one of the architectural best parts of the Omayyad Mosque. It was named because the architect who built it imagined the dome as a head of an eagle, and the aisles at its right and left as its wings.

An Arab historian wrote: if a person looks at the Eagle Dome from a certain distance he will have the impression of seeing an eagle. The head is the cupola, body is the prayer hall, and wings are the walls [18].

Further, the dome has a diameter of 16.6 meters, and a height of 43 meters from the ground level [19].

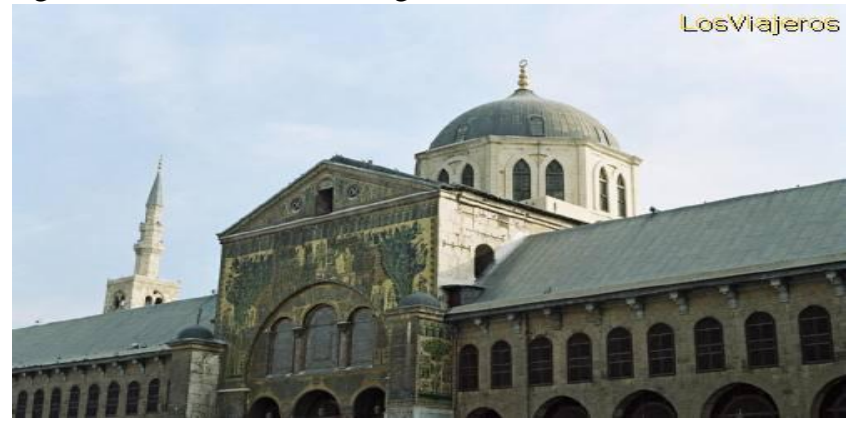

Fig. 6 represents Eagle Dome, Umayyad Mosque, Damascus, Syria, (Exterior) \& (Interior) [20].

\section{Fatih Mosque:}

Istanbul, Turkey
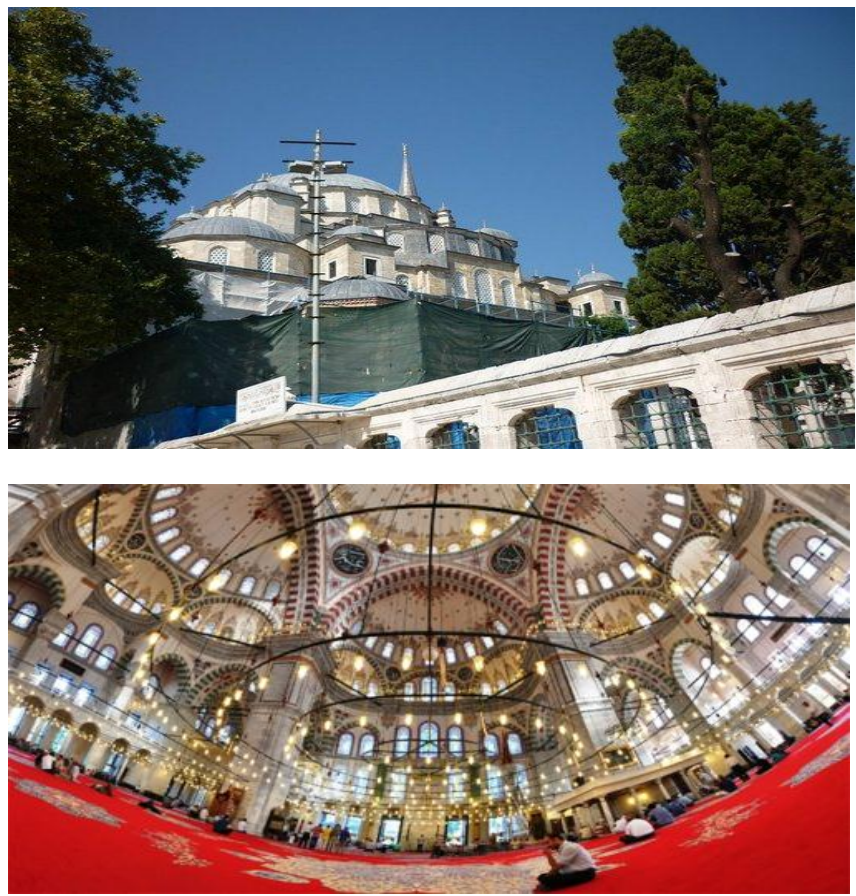

Fig. 7 shows Fatih Mosque, Istanbul, Turkey, Exterior) \& (Interior) 
Fatih Complex was built by Sultan Mehmet the Conqueror in the years 1463-1470. The complex includes a set of wellplanned buildings erected around a mosque [21].

\section{Shehzade Mosque}

\section{Istanbul, Turkey:}

The Shehzade Mosque is a 16th-century Ottoman imperial mosque found in the district of Fatih, on the third hill of Istanbul, Turkey. It was commissioned by Suleiman the Magnificent as a memorial to his son Şehzade Mehmed who died in 1543 [22].

The complex was Sinan's first valuable imperial assignment and eventually one of his greatest ambitious architectural works, even though it was designed early in his long career.

Entrance of the mosque is a marble-paved colonnaded with an area equal to that of the mosque itself. The courtyard starts with a portico with five domed bays on each side, with arches in pink and white marble [23].
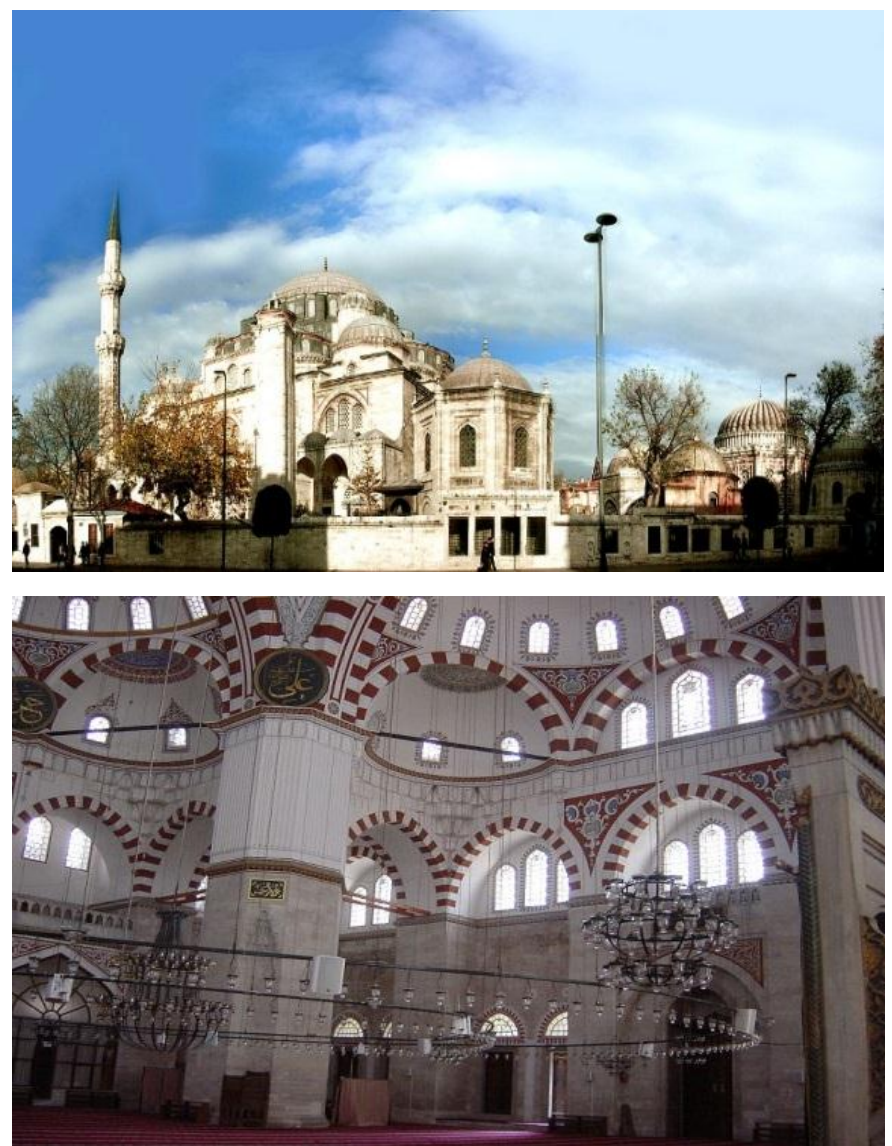

Fig. 8 shows Masjid Shahzade, Istanbul, Turkey, (Exterior) and (Interior)

The mosque itself has a square plan, covered by a central dome, flanked by four half-domes. The dome is supported by four pillars, with a diameter of 19 meters and a height of 37 meters. It was in this building that Sinan first adopted the technique of placing colonnaded galleries along the entire north and south facades to hide the buttresses [24].

\section{Suleymaniye Mosque}

Istanbul, Turkey:

The Süleymaniye Mosque is an Ottoman mosque located on the Third Hill of Istanbul. It is the largest mosque in the city.

The Süleymaniye Mosque built on the order of Sultan Süleyman to Architect Sinan. The construction work began in 1550 and the mosque was finished in 1558 [25].

This complex called the Süleymaniye has Islamic and Byzantine architectural elements. It combines tall, slender minarets with large domed buildings supported by half domes in the style of the Byzantine church Hagia Sophia [26].
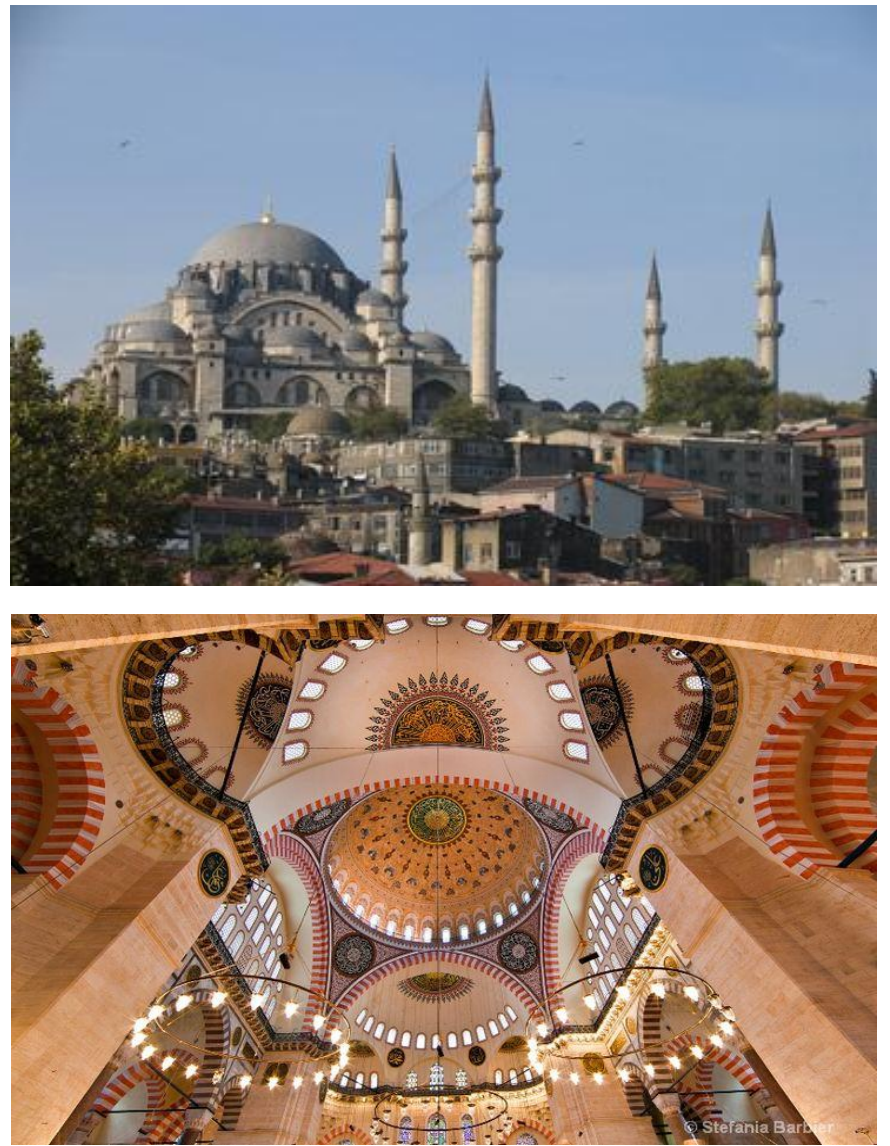

Fig. 9 shows Suleymaniye Masjid, Istanbul, Turkey (Exterior) and (Interior)

The Suleymaniye was restored in 1660 by Sultan Mehmed IV. Part of the dome collapsed again during the earthquake of 1766. Consequent repairs damaged what was left of the original decoration of Sinan.

Similar to the other imperial mosques in Istanbul, Suleymaniye mosque is preceded by a monumental courtyard on its west side. And, in the four corners of the courtyard are the four minarets,

The central dome is 53 meters high and has a diameter of 27.5 meters. At the time it was built, the dome was the highest in the Ottoman Empire, when measured from sea level, but still lower from its base and smaller in diameter than Hagia Sophia [27]. 


\section{Sultan Ahmed Mosque:}

\section{Istanbul, Turkey}

Sultan Ahmed Mosque or Sultan Ahmet Mosque is a historic mosque in Istanbul. The mosque is commonly known as the Blue Mosque for the blue tiles adorning the walls of its interior.

Ahmed I ordered to build the mosque in 1609, they finished construction in 1616. It contains a tomb of the founder, a school and a hospital. The Sultan Ahmed Mosque is still usually used as a mosque [28].
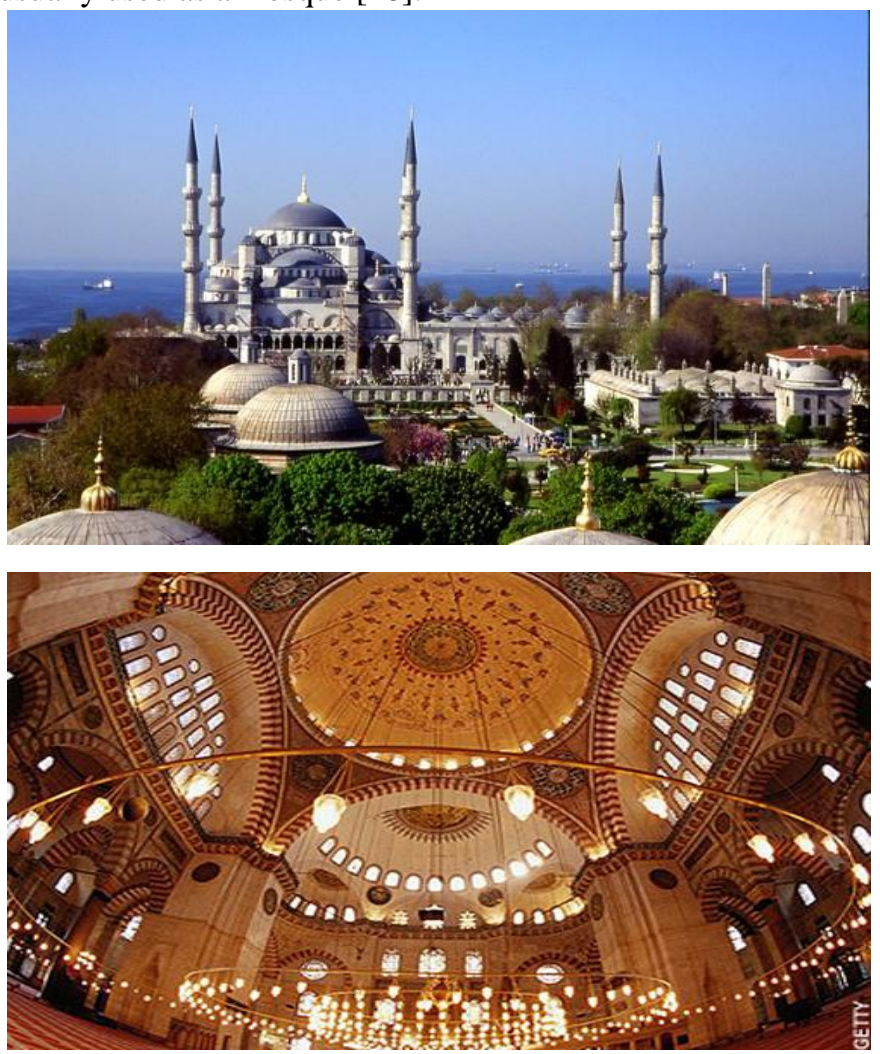

Fig. 10 shows Sultan Ahmed Masjid (Blue Masjid), Istanbul, Turkey, (Exterior) and (Interior)

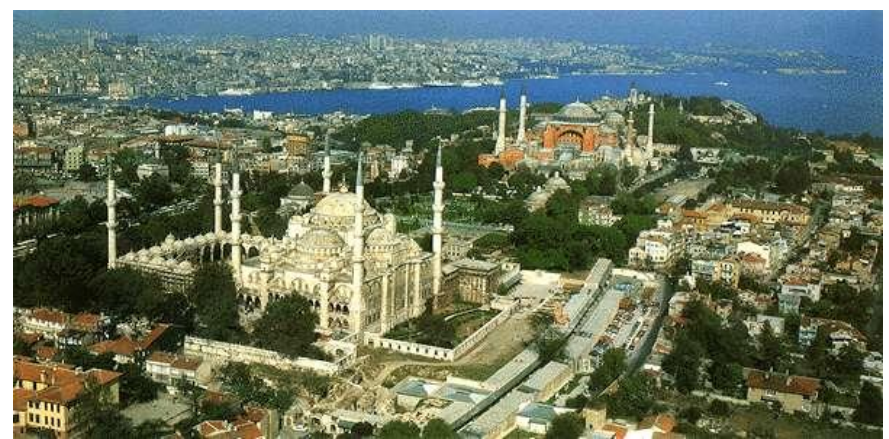

Fig. 11 shows Hagia Sophia, (the Church, Masjid and Museum) faces the later constructed Sultan Ahmed Masjid

The Sultan Ahmed Mosque has five major domes, six minarets, and eight secondary domes. The design is a result of two centuries of Ottoman mosque development. It includes some Byzantine Christian architecture of the neighboring Hagia Sophia with traditional Islamic architecture and is considered to be the last enormous mosque of the classical period. The architect, Mehmed Ağa, synthesized the ideas of his master Sinan, aiming for size, majesty and splendor [29]

\section{Suleyman Pasha Mosque, Jami' Sariyat al-Jabal: \\ Cairo, Egypt}

The Mosque of Suleyman Pasha, Jami' Sariyat al-Jabal is the first mosque constructed in Egypt under Ottoman Empire, it was built in 1528. The mosque is an essentially Ottoman style in plan. The prayer hall is covered by a shallow central dome in the Ottoman approach. This is fronted by a courtyard surrounded by domed arcades. The minaret is similarly Ottomans in form with a cylindrical, faceted and a shaft found to the right of the entrance façade [30]. The interior reflects the outward Byzantine and Ottoman form with the dome resting on spherical pendentives, and is decorated with marble, engravings, painting, and stucco [31].
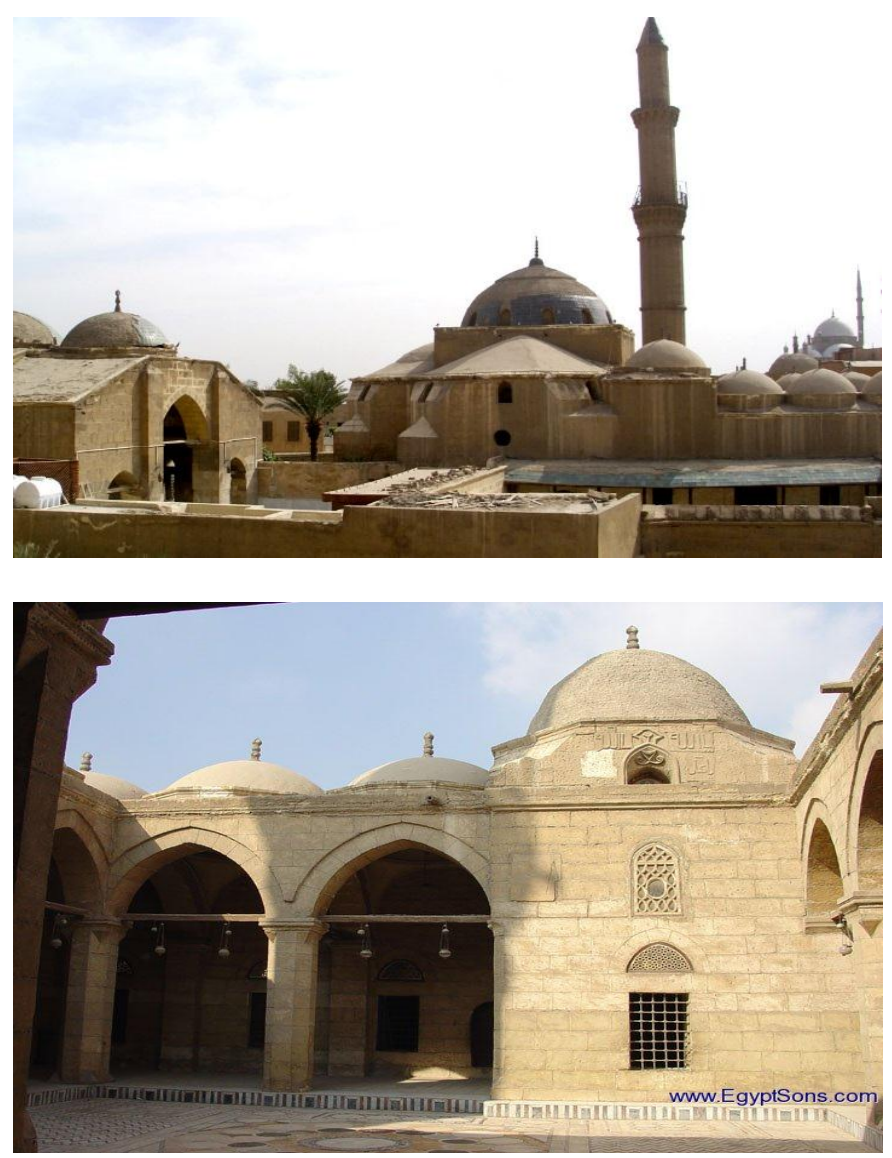

Fig. 12 represents Masjid Sulaiman Basha, Saryat al Jabal, Saladin Castle, Cairo, Egypt, (Exterior) and (Interior)

\section{Muhammad Ali Pasha Mosque}

\section{Cairo, Egypt}

The Mosque of Muhammad Ali Pasha or Alabaster Mosque is a mosque found in the Citadel of Cairo in Egypt, commissioned by Muhammad Ali Pasha between 1830 and 1848 [32].

Muhammad Ali chose to build his state mosque in the 
architectural style of the Ottomans. The mosque was built with a central dome bordered by four small and four semicircular domes. Besides, the plan of the mosque is square, the same style of Hagia Sophia measuring $41 \times 41$ meters. The central dome is 21 meters in diameter and the height of the building is 52 meters. Further, it has two elegant minarets of Turkish type, and rise to 82 meters [33].
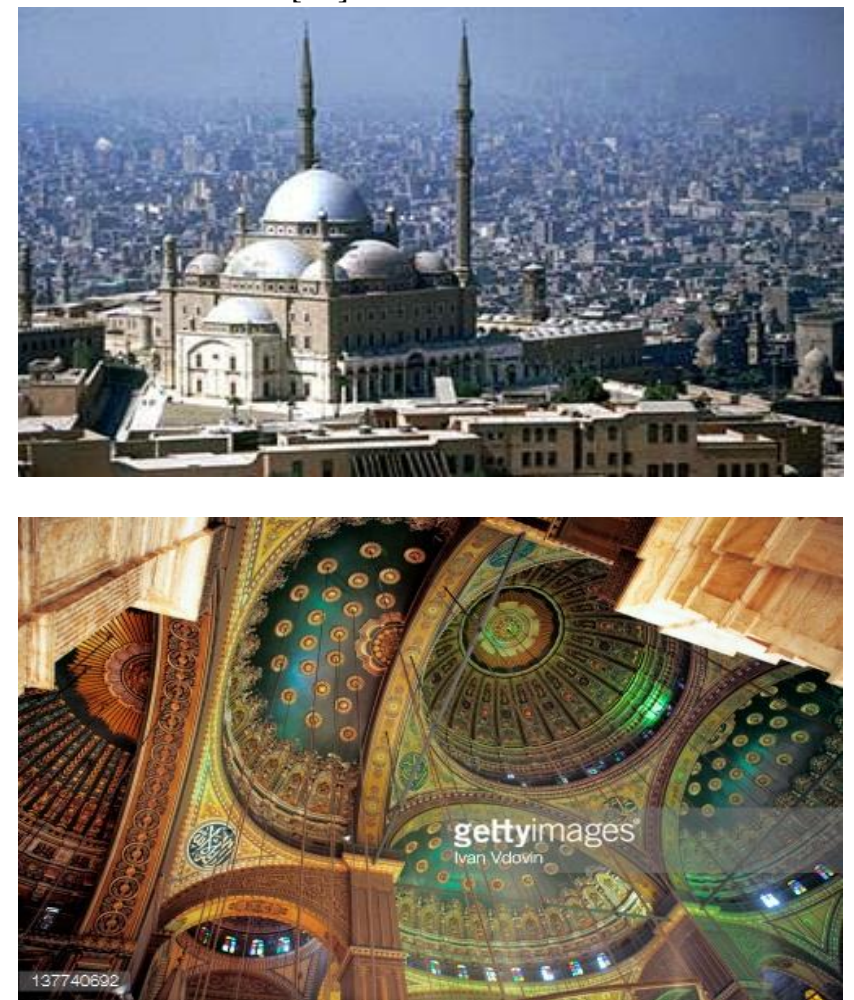

Fig. 13 shows Masjid Mohammad Ali Basha, Saladin Castle, Cairo, Egypt, (Exterior) and (Interior)

\section{MOdern Muslim MosQues}

\section{Al Hussain Bin Talal Mosque:}

\section{Madaba, Jordan}

Al-Hussein Bin Talal Masjid is located in Madaba in Jordan. Its first construction dated back to 1929 A.D. The present restoration started in 1997 A.D and finally, the project was inaugurated on 12/3/2008 [34]. It has a central dome with 12 meters diameter, and a height of 23 meters.

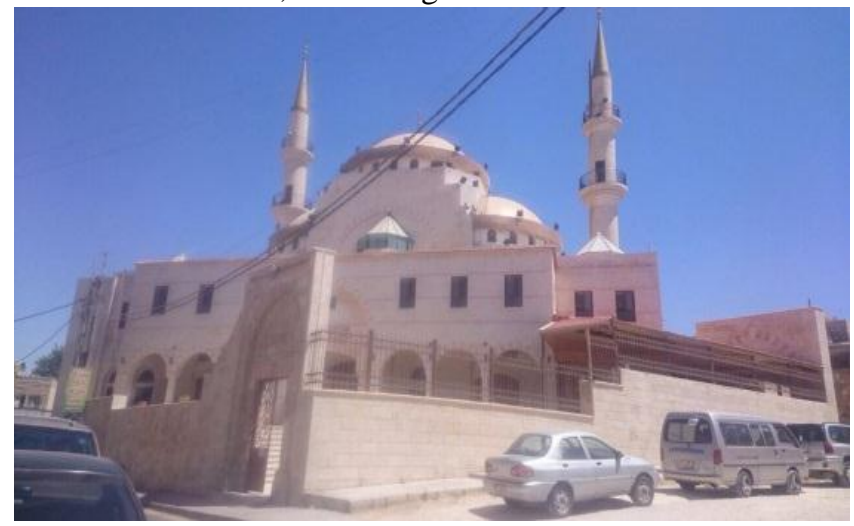

Fig. 14 represents Al Hussain Bin Talal Mosque:,Madaba, Jordan Pictured by Rawshan Saleem Al manaie [35].

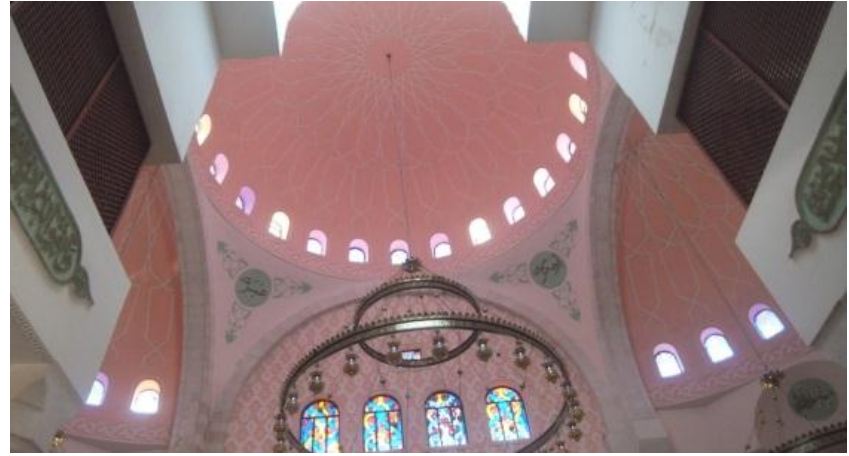

Fig. 15 represents Al Hussain Bin Talal Mosque, Madaba, Jordan. Pictured by Sujood Al Najar [36].

\section{Wilayah Persekutuan Masjid}

\section{Kuala Lumpur, Malaysia}

Wilayah Persekutuan Masjid (Federal Territory) was constructed in 1998 on a land of 50,000 square meters. Further, it was opened to the public on 25 October 2000. The mosque can accommodate 17,000 people at any one time.

The mosque's design is a combination of Ottoman and Malay architectural styles, heavily influenced by the Blue Mosque in Istanbul, Turkey. It has 22 domes made from a composite material of glass fiber fabric mixed with epoxy to make it durable and light [37].
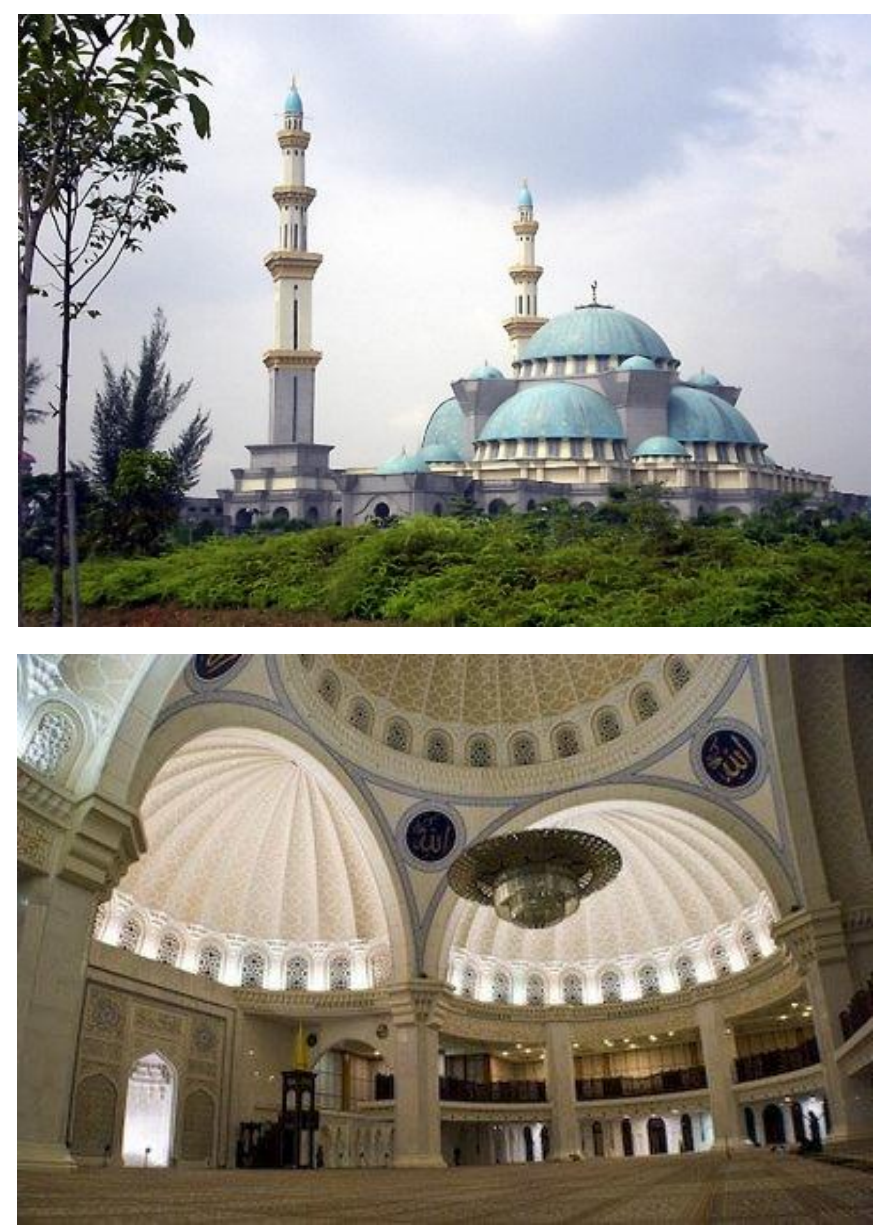

Fig. 16 shows Masjid Wilayah Persekutuan, Kuala Lumpur, Malaysia 


\section{Mohammad al-Amin mosque}

\section{Lebanon, Beirut}

The Mohammad Al-Amin Mosque is located in downtown Beirut, Lebanon. Originally in the 19th century, a prayer corner was built on this site; subsequently it took people decades to buy enough land bordering to the prayer corner. Finally, they succeeded to build the latest mosque.
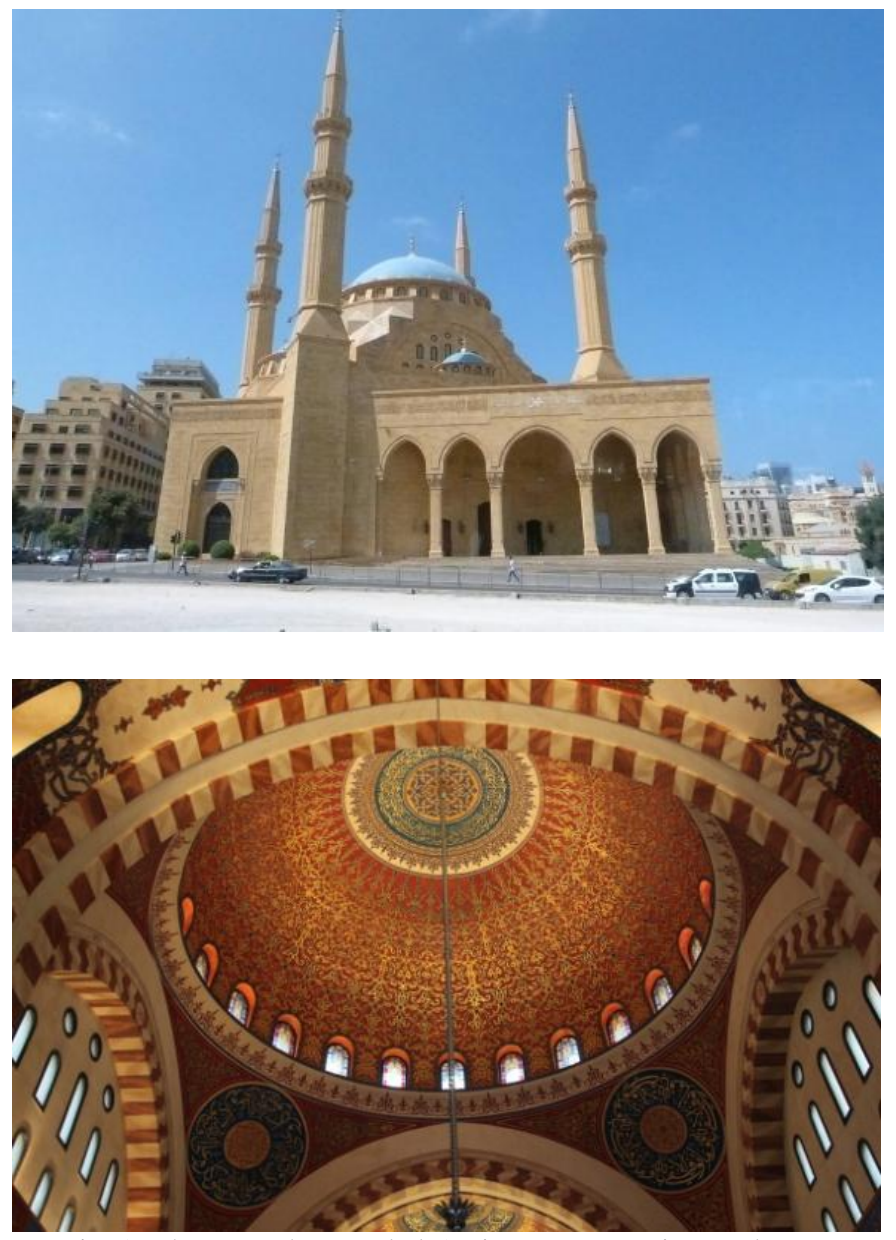

Fig. 17 shows Mohammad al-Amin mosque, Beirut, Lebanon, (Exterior) and (Interior)

The dome and minarets of Beirut's Mohammad al-Amin mosque were completed in 2005. But, authorities inaugurated it in 2008 [38]. Its minarets are 72 meters high influenced by those of Mecca's Grand Mosque. The dome is inspired by Ottoman mosques which were in turn influenced by Istanbul's Byzantine-era Hagia Sophia [39].

\section{CONCLUSIONS}

It is observed that, Hagia Sophia was a source of encouragement for Ottoman architects and engineers, so was Byzantine architecture. Besides, such influence exceeded Ottoman buildings to all Muslim mosque architecture.

The small square-plan mosque, topped with a circular dome is a feature of Ottoman architecture. Ottoman mosques performed gradually large central domes covering larger interior square volumes. It was the influence of Hagia Sophia, after the conquest of the Byzantine capital, which marked a turning point in the history of Ottoman and Muslim architecture. However, majority of enormous mosques have same style of Hagia Sophia, like: the mosque of Mehmed II, Mosque of Bayazid, Mosque of Süleyman, Mosque of Ali Paşa, and the mosque of Selim II that he built in Edirne.

The architectural style of the Hagia Sophia continued to be imitated, adapted and reinterpreted, as a direct prototype for all new mosques. Nevertheless, Muslim architects, Sinan chief among them, and several others had later immersed into their work the architectural concepts of Hagia Sophia.

\section{RECOMMENDATIONS}

This study recommends paying attention to the importance of Hagia Sophia in the history of architecture. It focuses on influence of the building on Muslin mosques. The study shows a real need for analyzing the contemporary built mosques to find out the traditional architectural elements found there.

This Paper suggests that architects and engineers should enrich their experience by analyzing the dome structure in the building of Hagia Sophia and other similar mosques.

\section{REFERENCES}

[1] Grupico, Theresa, The Dome in Christian and Islamic Sacred Architecture, Monmouth University, West Long Branch, NJ, p.4

[2] Helen Gardner and Fred Kleiner Art Through the Ages. 2004 edition Mamiya, USA

[3] Eugene Kleinbauer, W, Indiana University professor, in a section of the book "Hagia Sophia" (Scala Publishers, 2004).

[4] Durant, W, and A, The story of civilization, Simon and chuster, New York, 1954, Vol. 6, Capter 12, Pp. 263, 264 / ॰1408 -( 264,263) - 1988

[5] Panayotis A. Michelis - An Aesthetic Approach to Byzantine Art B.T. Bats ford Ltd. 1955 London

[6] Victoria Hammond, who describes the structure of the surviving Hagia Sophia dome, "Visions of Heaven: The Dome in European Architecture" (Springer, 2005).

[7] Haddad, M. H., Encyclopedia of Islamic Architecture, Eastern Publisher, Cairo, Egypt, Pp, 189,190

[8] Grabar, O. The Islamic Dome. Some Considerations. Journal of the Society of Architectural Historians. Dec. 1963. Vol. 22. No. 4, pp. 191-198; Lehmann, K. The Dome of Heaven. The Art Bulletin. Mar. 1945. Vol. 27. No. 1, pp. 1-27

[9] Elisabeth Piltz in a 2005 British Archaeological Reports series book.

[10] Kleiner writes (in a 2010 edition of his book)

[11] Robert Nelson, "Hagia Sophia: 1850-1950: Holy Wisdom Modern Monument," University of Chicago Press, 2004)

[12] Mustafa, Saleh, L., Domes in Islamic Architecture, Arabian Renaissance, Bierut, Lebanon, P. 11

[13] Haddad, M. H., Encyclopedia of Islamic Architecture, Op. Cit

[14] Qaisi, M. Mosques ( Tradition and innovation), Ammar publications, Cairo, P-p 19-29

[15] Adopted from an American Muslim Council (AMC) special report. This article appeared in The American Muslim, Spring 1994, as "Palestine: Land of Divine Revelation."

[16] https://www.google.com/search?q=Lebanon,++Beirut+Mohammad+alAmin + mosque \&source $=\operatorname{lnms} \&$ tbm $=i s c h \& s a=X \& v e d=0 a h U K E w j j 4 d m$ Vk73LAhXKWxoKHeFnC7IQ_AUIBygB\&biw=1600\&bih=767\#tbm $=$ isch \& $\mathrm{q}=$ dome + of + the + rock $+3 \mathrm{~d}+$ model $\&$ imgrc $=$ CCRWYwPTtZ3pC $\mathrm{M} \% 3 \mathrm{~A}$

[17] Grabar, O, The Shape of the Holy: Early Islamic Jerusalem. 1996. Princeton, Princeton University Press. 104-109

[18] E. Claire Grimes, A guide to Damascus, Avicenne Bookshop, 1997

[19] http://www.discover-syria.com/bank/129 
[20] https://www.google.com/search?q=Lebanon,++Beirut+Mohammad+alAmin + mosque \&source $=1 \mathrm{nms} \& \mathrm{tbm}=\mathrm{isch} \& \mathrm{sa}=\mathrm{X} \& \mathrm{ved}=0 \mathrm{ahUKEwjj} 4 \mathrm{dm}$ Vk73LAhXKWxoKHeFnC7IQ_AUIBygB\&biw=1600\&bih=767\#tbm $=$ isch $\& \mathrm{q}=$ eagle+dome $\&$ imgrc $=$ OQfvggi9iB5XJM\%3A

[21] https://www.istanbulhotels.com/travel/fatih_mosque.html

[22] Necipoğlu, Gülru (2005). The Age of Sinan: Architectural Culture in the Ottoman Empire. London: Reaktion Books.p,p 191,192

[23] Ibid, .p.196

[24] Ibid, .p.121

[25] https://en.wikipedia.org/wiki/S\%C3\%BCleymaniye_Mosque

[26] https://en.wikipedia.org/wiki/S\%C3\%BCleymaniye_Mosque

[27] Necipoglu-Kafadar, Gulru (1985). "The Süleymaniye Complex in Istanbul: An Interpretation". Brill. http://dx.doi.org/10.2307/1523086

[28] "Blue Mosque". sultanahmetcamii.org. Retrieved 15th. March, 2016

[29] Architecture". sultanahmetcamii.org/architecture-of-the-mosque/. Retrieved 15th. March, 2016

[30] Behrens-Abouseif, Doris. Islamic Architecture in Cairo. Leiden: E. J. Brill, 1989.

[31] Zaki, A., Saladdin Castle and Surroundings, Public Egyptian Publishers, Cairo, 1971, P. 30

[32] Okasha, Alyaa, Islamic Architecture in Egypt, Barada publications, Cairo, 2008

[33] https://en.wikipedia.org/wiki/Mosque_of_Muhammad_Ali

[34] Documents of Ministry of Endowment, Madaba department, 2015

[35] Architecture student, University of $\mathrm{Al}$ al-Bayt, Jordan

[36] Architecture student, University of Al al-Bayt, Jordan

[37] -http://masjidwilayah.gov.my/v1/

[38] https://www.google.com/search?q=Lebanon,++Beirut+Mohammad+alAmin + mosque \&source $=1 \mathrm{nms} \& \mathrm{tbm}=\mathrm{isch} \& \mathrm{sa}=\mathrm{X} \& \mathrm{ved}=0 \mathrm{ahUKEwjj} 4 \mathrm{dm}$ Vk73LAhXKWxoKHeFnC7IQ_AUIBygB\&biw=1600\&bih=767\#imgr c=Rkaav4_QiebbzM\%3A

[39] http://www.reuters.com/article/us-lebanon-mosqueidUSTRE49G4HQ20081017 